\title{
INTERNAL GEOMETRY AND EVOLUTION OF MOULINS, STORGLACIÄREN, SWEDEN
}

\author{
By Per Holmlund
}

(Department of Physical Geography, University of Stockholm, S-106 91 Stockholm, Sweden)

\begin{abstract}
The initial conditions needed for formation of moulins are crevasses and a supply of melt water. Water pouring into a crevasse may fill it until it overflows at the lowest point, which is normally near the margin. However, as the crevasse deepens, it intersects englacial channels through which the water can drain. These channels may be finger-tip tributaries in a dendritic system such as that described by Shreve (1972) and observed by Raymond and Harrison (1975). When the crevasse closes, heat in the melt water keeps the connection open and a moulin is formed. The englacial channel enlarges rapidly by melting, utilizing mechanical energy released by the descending water.

Descents into moulins, and mapping of structures exposed at the surface after many years of melting, demonstrate that the drainage channels leading down from the bottoms of the moulins have inclinations of $0-45^{\circ}$ from the vertical. These channels trend in the direction of the original crevasse but appear to be deeper than the expected depth of the crevasse. They have not, even at depths of $50-60 \mathrm{~m}$, become normal to the equipotential planes described by Shreve.
\end{abstract}

\section{INTRODUCTION}

Moulins, or "glacial mills" as they are sometimes called, are one of the more dramatic features of glacier surfaces. Water plunging into a large moulin presents an awesome sight, the more so because of the realization of the consequences of a false step. Perhaps partly because of this, moulins do not seem to have received the scientific attention they deserve.

Moulins are important for a number of reasons; perhaps the most significant of these is that they are one end of an otherwise virtually unknown englacial water system. As moulins form, evolve, and eventually become inactive, so must the englacial water system change. What determines where moulins form? What determines their depth? What do they look like below the surface?

To answer some of these questions, a program of monitoring moulins and their evolution was initiated on Storglaciären in northern Sweden (Fig. 1) in 1978. The study covers approximately 70 moulins. Maps were made showing locations of moulins, and some were numbered to indicate the year in which they formed (77:1 and so forth) (Fig. 2). Water-pressure measurements were initiated in some moulins in 1981, and have been described by Holmlund and Hooke (1983). Additional observations were made during several descents into dry moulins prior to the start of the melt season. Finally, 34 moulins were mapped frequently between 1981 and 1987 as deeper levels were gradually exposed by melting on the glacier surface.

\section{INITIAL DEVELOPMENT AND EVOLUTION OF MOULINS}

Because the top $30-40 \mathrm{~m}$ of the lower part of Storglaciären is a few degrees below the pressure-melting

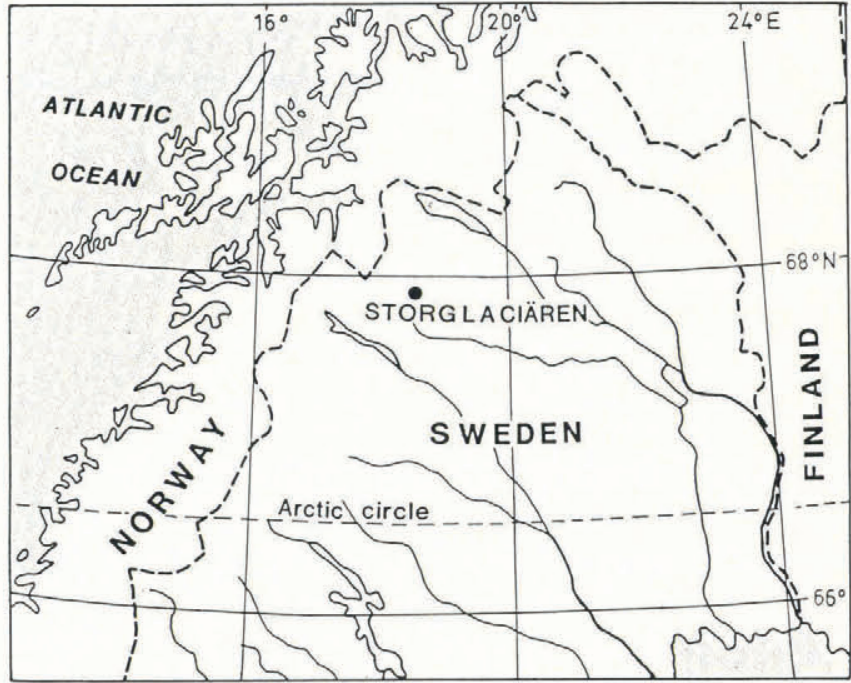

Fig. 1. Map showing the location of Storglaciären.

point (Schytt, 1968; Hooke and others, 1983), the ice surface is presumably impermeable. Thus, the only way for water to find its way down into the glacier is through crevasses. The input of water to the englacial water system is therefore limited to places with high extending strainrates near the surface, as it is in such places that crevasses form. The main location is an area close to the center line of the tongue of Storglaciären where there are crevasses caused by flow over a riegel on the glacier bed (Figs 2 and 3).

Many crevasses open across surface streams. In some cases, water fills the crevasse until it overflows at its lowest point. In others, water goes in and does not fill the crevasse. In these cases, the crevasse may have been deep enough to reach ice at the pressure-melting point, where it may have intersected small channels such as those observed in cores by Raymond and Harrison (1975). These may be finger-tip tributaries of a dendritic network such as that described by Shreve (1972). When glacier flow moves the crevasse into an area of compression, the crevasse closes, but heat carried in the melt water as well as viscous energy dissipated from the melt water may keep drainage channels open.

The ice surface up-glacier from the main moulin area on Storglaciären is even and gently sloping, so there is an abundance of melt water running on the surface. The position of the melt-water channels is relatively constant from year to year. Thus, when new crevasses open up-glacier from an old moulin, intersecting the stream to that moulin, a new moulin is formed. This process is repeated approximately annually, creating trails of moulins with increasing age in the down-glacier direction. The oldest, at the down-glacier end of the trail, appears only as 


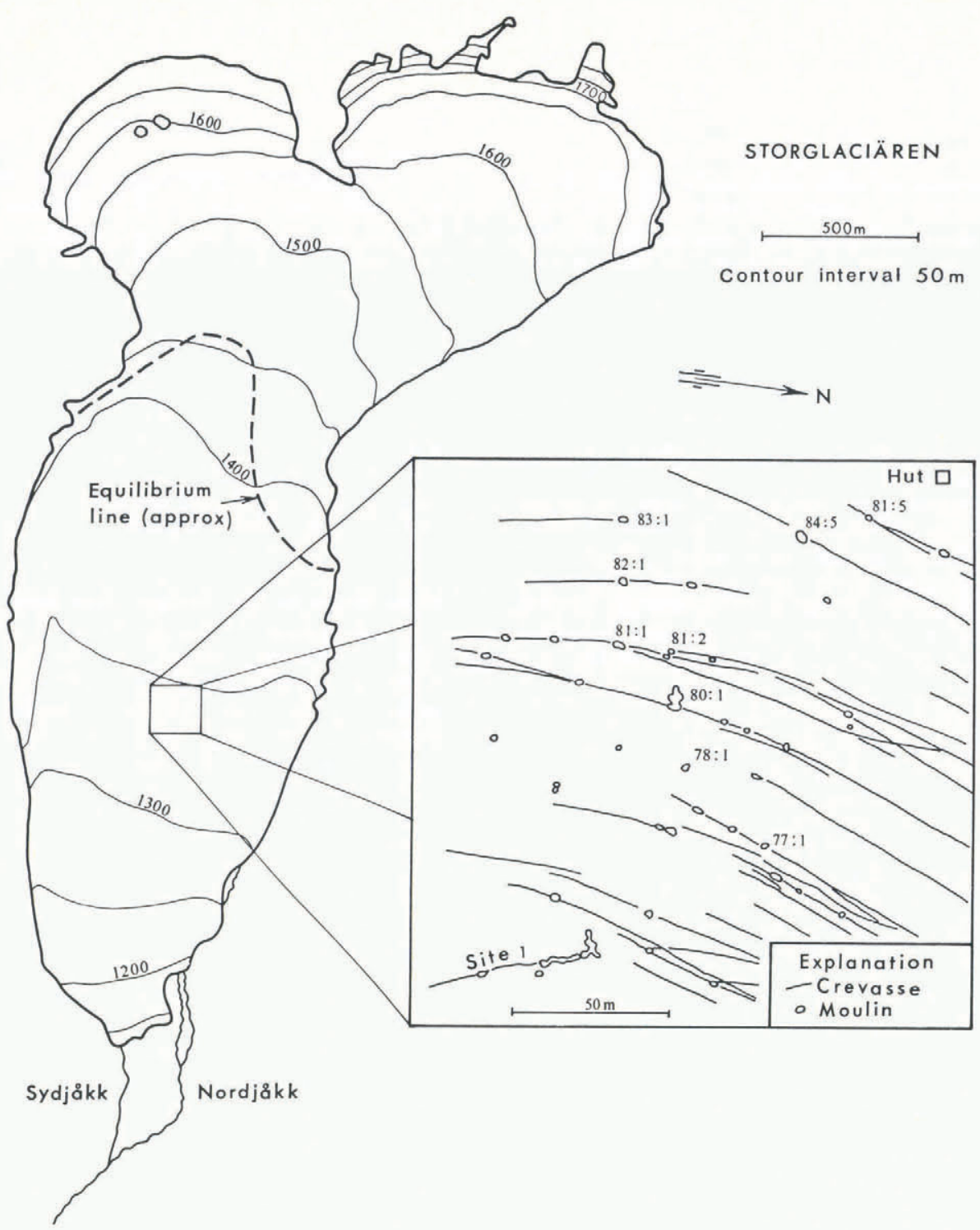

Fig. 2. Map of Storglaciären showing the location of moulins mentioned in the text.

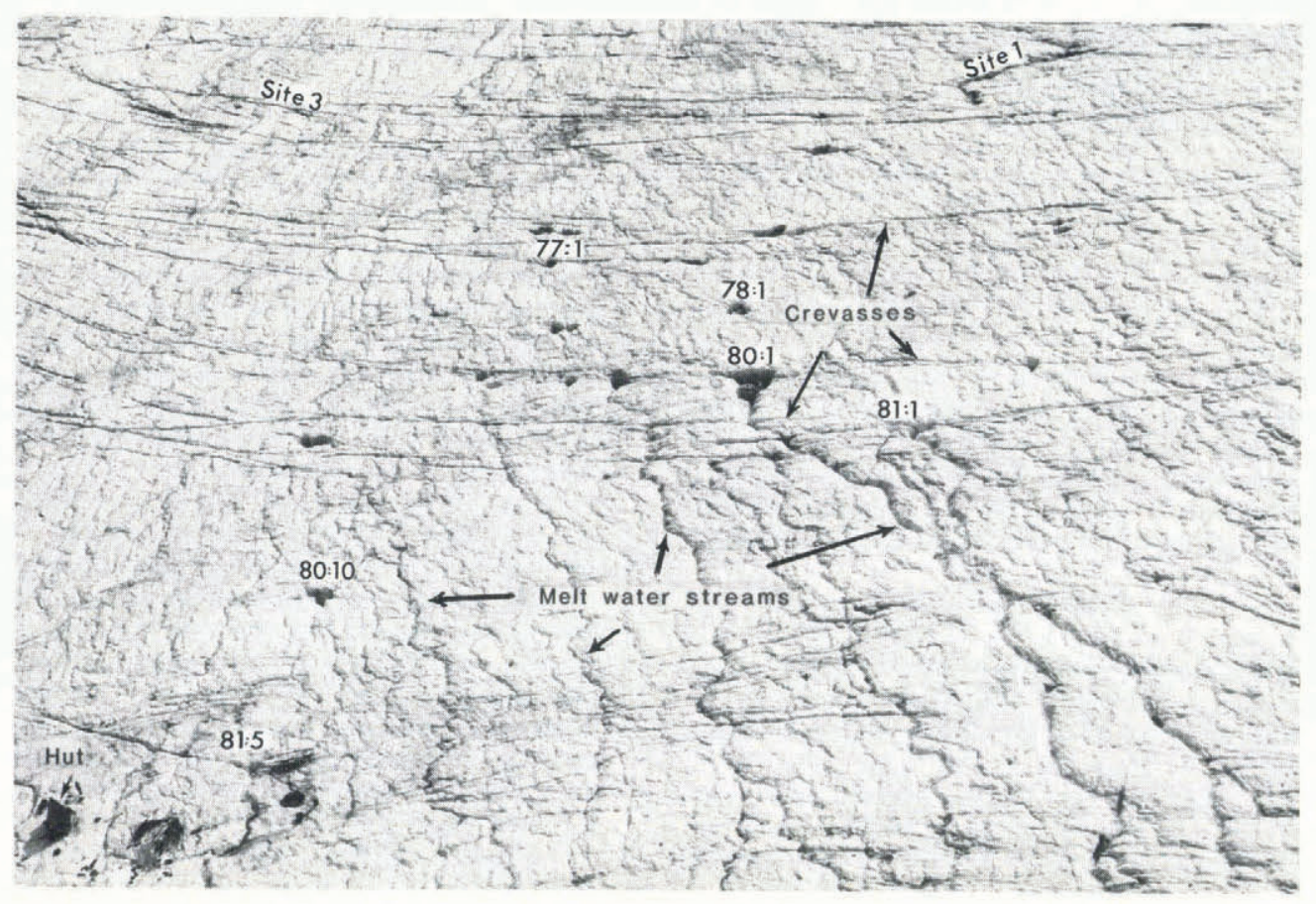

Fig. 3. Oblique aerial photograph of the main moulin area on Storglacidren. View is down-glacier, and shows features identified in the inset of Figure 2. (Photograph taken by J. Kleman, 19 August 1981.) 
a characteristic structure in the ice at the surface. As long as such moulins still have contact with the englacial water system, they can remain open if the small amount of melt water collected locally can open a channel through the winter snow that fills the moulin.

Eventually, such moulins become inactive, either because the small amount of melt water draining into them cannot maintain a channel or because changes within the ice or at the base of the glacier cut the connection to the subglacial drainage system. The moulin then fills with water. If there is abundant saturated snow in this filling, it will look like porous superimposed ice when it freezes. This ice is fine-grained (grain-size $\sim 5 \mathrm{~mm}$ ) with a rather high porosity. It looks like 3 or 4 year old firn in a temperate glacier. In the absence of such snow, the deeper water freezes within a few days or weeks, depending on the moulin size. However, during the first melt season the top $1-3 \mathrm{~m}$ remains open, because heat loss to the warmer surface ice is less rapid than heating by solar radiation. Water has a lower albedo than ice and therefore absorbs more solar energy. These surface pools freeze during the winter or drain as ablation lowers the ice surface. In this case, the resulting structures appear as a concentric pattern of ice crystals with a more or less circular boundary (Fig. 4). These were referred to as "crystal quirkes" by Stenborg (1968).

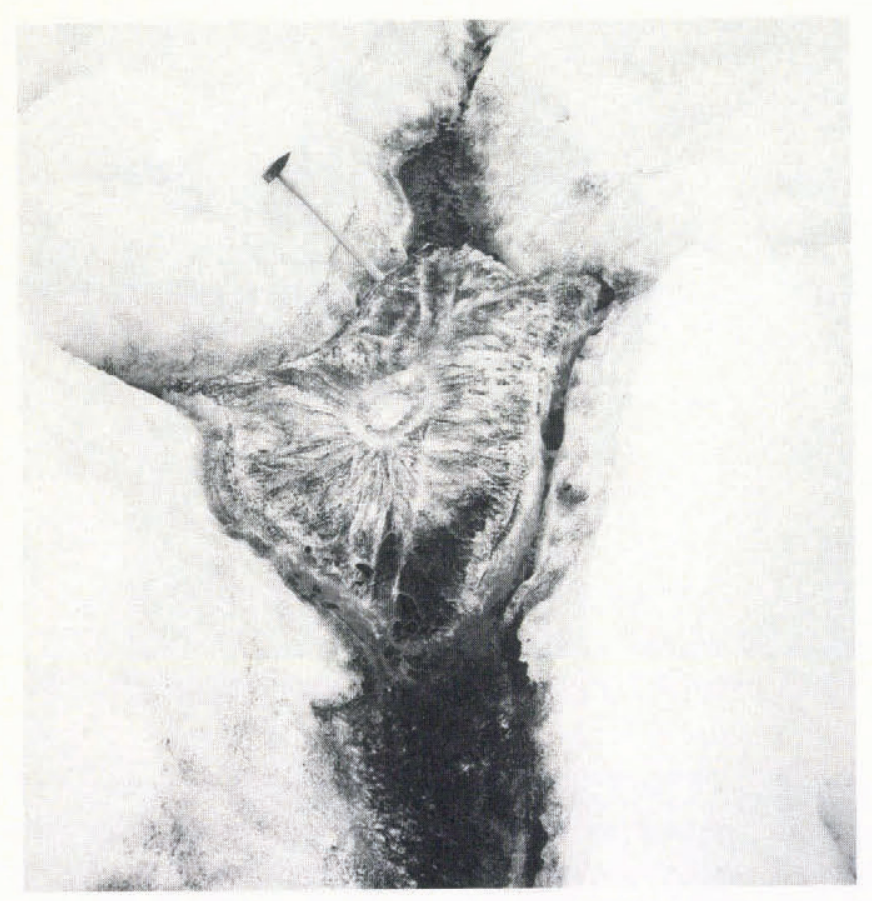

Fig. 4. Concentric ice pattern in a fossil moulin, referred to as a "crystal quirke" by Stenborg (1968).

\section{FIELD TECHNIQUES}

\section{Descents into moulins}

During the winter, when there is no water running into these moulins, it is possible to descend into them. Their positions are marked by steel rods in the late summer so they can be found easily during the winter. The descents have been accomplished using standard mountaineering techniques. A total of seven moulins was studied through descents.

\section{Mapping}

Maps of fossil moulins have been constructed at two different scales. The general maps were made at a scale of 1: 1000 and covered an area of about $200 \mathrm{~m} \times 300 \mathrm{~m}$. More detailed maps are at a scale of $1: 100$ and cover each individual structure. The purpose of the general maps was to keep track of the formation of new moulins and of deformation caused by differences in surface velocity. Since 1978, this mapping has been done with a Wild T-2 theodolite and an AGA geodimeter. Prior to 1978, there were maps based on air photographs from 1968, 1969, 1970, and 1972 .
All of these maps were related to the same local coordinate grid. Comparison then yielded information about the time of formation of individual moulins. Furthermore, with the use of ablation data on nearby stakes, the original depth at which a given structure was formed could be determined.

The detailed maps are made in the field with a measuring tape. Each covers a complex of structures, such as that in Figure 5a, with an accuracy of about $10 \mathrm{~cm}$. Boundaries of the structures are mapped as well as the ice type in them, whether superimposed ice formed from frozen water-soaked snow or frozen water bodies with their typical concentric crystal pattern. In addition, all kinds of melt-out debris, such as stones, dead lemmings, and debris from previous scientific experiments have also been mapped. Such maps are made three or four times a year. Using them together with ablation data, it is possible to build up a three-dimensional picture of the moulins (Fig. 5b). The detailed maps cover 34 moulins and the smaller-scale maps cover another 40-50 moulins.

\section{Water levels in moulins and bore holes}

Water-level studies in moulins were initiated in 1981. Since 1982, this part of the project has also included a study of water levels in bore holes. Water levels are measured with the use of pressure transducers at the bottoms of moulins or at known depths in the bore holes. The output from the transducers is recorded on a chart recorder in a hut on the glacier (Fig. 2). The transducers used were originally made for measuring oil pressure in car engines. In clear water they can continue to function for about 2 years, but in turbid water they may become clogged in only a couple of days. They are calibrated by being lowered progressively into a lake or bore hole with a known water-surface elevation or by measuring water levels manually during high-water events in the glacier.

During days with a large input of melt water or rain water, the water level in the glacier increases and may reach levels that, if there were a direct connection to the bottom, would correspond to a pressure at the base of the glacier that exceeds the weight of the overburden ice (Holmlund and Hooke, 1983).

\section{RESULTS}

\section{Descents into moulins}

There are only a few previously published descriptions of the internal geometry of a moulin (Vallot, 1898; Dewart 1966; Reynaud, 1987), and apparently no detailed measurements of this geometry. Dewart (1966) worked on Kaskawulsh Glacier in Yukon Territory. He described most moulins on the glacier as vertical shafts with more or less prominent shelves at depth. The single moulin that he investigated in detail decended stepwise via two vertical shafts and one cork-screw passage to a ledge about $20 \mathrm{~m}$ below the surface. At the end of the ledge the tunnel dropped vertically again. According to his observations, this type of moulin, leading down stepwise into the glacier, was not as common as the vertical ones (Dewart, 1966). Vallot (1898) and Reynaud (1987) described the "Grand Moulin" on Mer de Glace in the Mont Blanc Massif, France. This is a large moulin that re-appears each year at the same place on the glacier. They described the moulin as an open shaft 60-70 $\mathrm{m}$ deep with small shelves at different elevations. At 60.5 (Vallot, 1898) and at $71.5 \mathrm{~m}$ (Reynaud, 1987), respectively, they found a well-defined bottom with a shallow plunge pool. In his descent in 1897, Vallot did not go further down but he showed on a sketch that the moulin was drained by a rather narrow channel with an inclination less than $45^{\circ}$. In 1986, Reynaud climbed further down into the drainage channel and managed to reach a depth of approximately $100 \mathrm{~m}$. The drainage channel dipped at $50-60^{\circ}$ down-glacier and showed a weak tendency to meander (Reynaud, 1987, fig. 2).

On Storglaciären, the top $25-30 \mathrm{~m}$ of a moulin, within the cold surface layer, is normally straight and vertical. Below this, the moulins widen and their geometry becomes more complicated as a result of higher rates of melting and closure, respectively, compared to the top layer. 
a

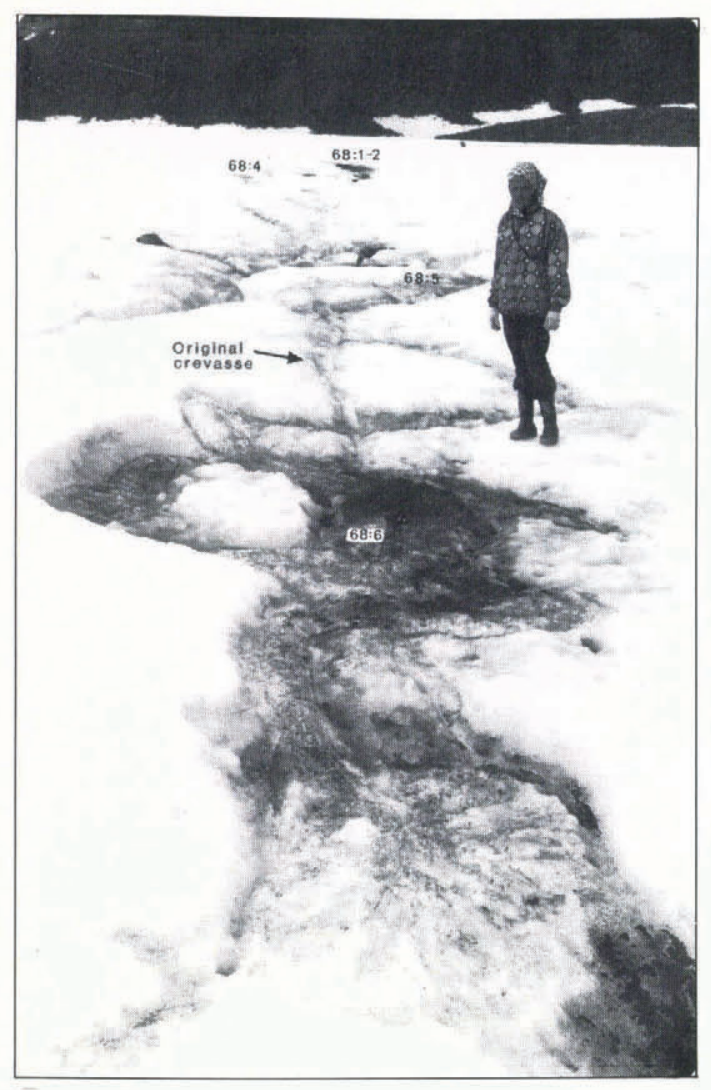

b

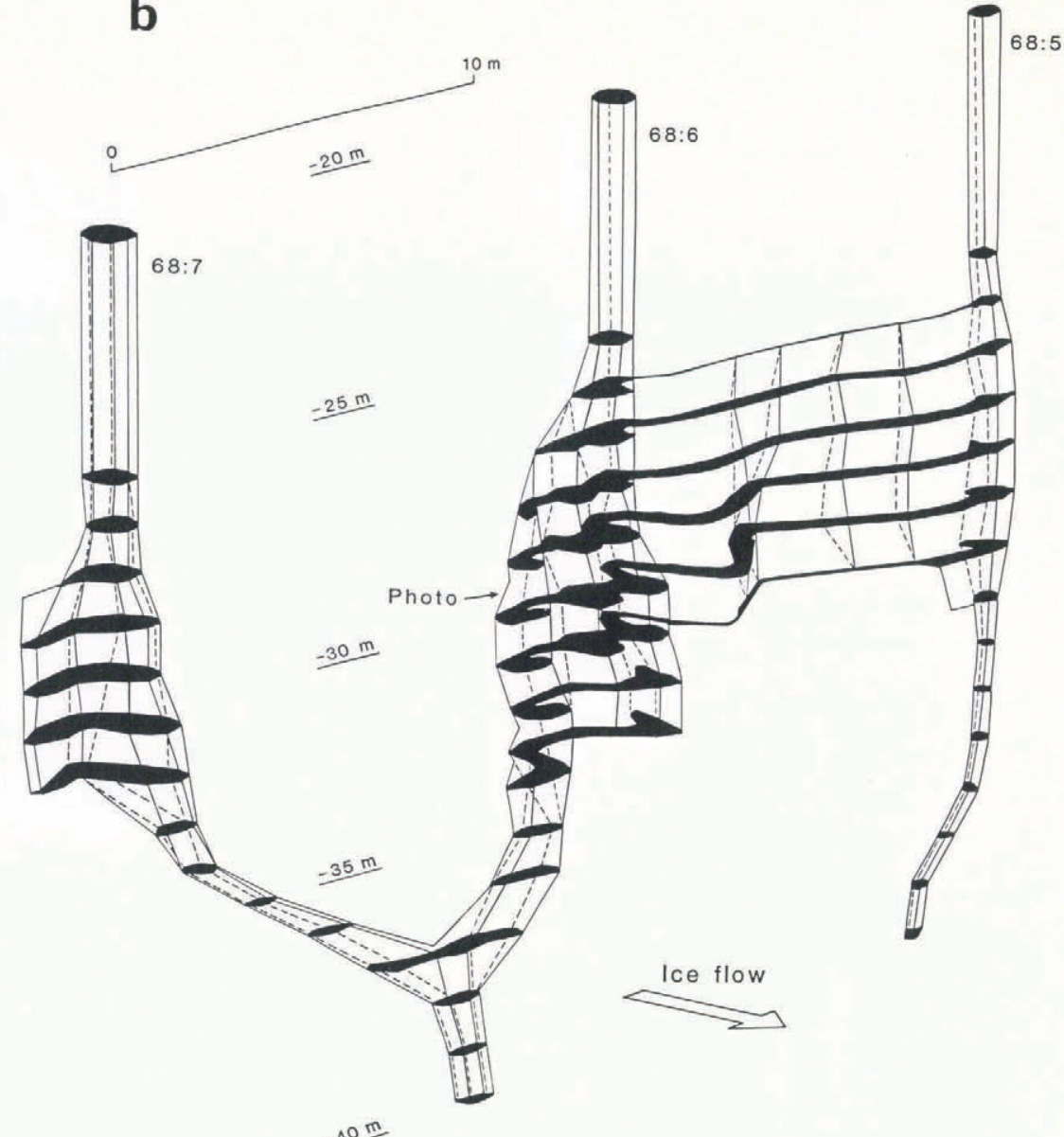

Fig. 5. Result of detailed large-scale mapping. a. Photograph of moulins 68.5 and 68.6 on 2 August 1982. b. Three-dimensional drawing showing interpretations from mapping of moulins 68:5, 68:6, and $68: 7$ with vertical spacing based on measured ablation. The drawing shows the geometry of the moulins between 20 and $40 \mathrm{~m}$ below the 1968 surface. The gradual uncovering of this sequence took about 10 years.

The bottoms of moulins are well defined in most of the cases investigated. Shallow plunge pools are common but the frequency of their appearance seems to be a function of the angle of the deeper drainage channel. In moulins drained at a steep angle, plunge pools are absent. In some cases, one could stand at the bottom of a moulin and, through a narrow passage trending in the direction of the original crevasse, see another vertical shaft some meters away. These secondary vertical shafts have, in some cases, connections with the surface. The narrow passage showed evidence of being a drainage way between the two shafts.

Most moulins are drained by two channels, one almost horizontal along the bottom of the original crevasse and, at a greater depth, another at the bottom of the moulin. The former is older; it is now used only during high-water situations. The younger, lower one, usually dips downwards at approximately $45^{\circ}$ in the direction of the original crevasse.

The older channels are generally narrow and high. In moulin 78:1 (Fig. 6), one was approximately $5 \mathrm{~m}$ high and $0.4 \mathrm{~m}$ wide after the 1978 melt season, when this program was started. In moulin $81: 1$ there were two drainage channels at different elevations after the 1982 melt season. The upper one was fossil and was $2 \mathrm{~m} \mathrm{high}$ and $0.4 \mathrm{~m}$ wide. The top of the lower was less than $0.5 \mathrm{~m}$ below the bottom of the upper one, and was also about $2 \mathrm{~m}$ high. As we know that moulin 81:1 was formed in 1981, we conclude that the bottom-melt rate over those 2 years was about $2 \mathrm{~m}$, which is comparable to the ablation rate on the surface.

The drainage channels in both of these moulins were meandering. The amplitude of the meanders was $1-1.5 \mathrm{~m}$, or two to three times the width of the channel. The fact that they meander indicates that melt water was probably flowing at high speed with a Froude number in excess of unity (Parker, 1975).

There were small conduits entering moulins 78:1 and 81:1 (Fig. 7) at different depths. These were located along the trace made in the side of the moulin when the original crevasse closed.

The tendency for moulins to widen at greater depth must be caused by relatively high melt rates. These melt rates cannot be explained by taking into account only differences in the ice temperature with depth (Fig. 7), since the heat capacity is negligible compared with the heat of fusion in ice. Photographs taken $15-20 \mathrm{~m}$ below the surface by remote techniques in active moulins during the melt season show that the water stream is split up into a spray at that depth. Thus, much of the water probably strikes and then flows down along the walls below this depth. The heat transfer is then much more efficient than higher up where the melting is mainly a result of heat transfer from the air to the ice.

\section{Mapping}

The detailed maps have shown that a complicated network of channels exists between different moulins (Figs 5 and 8 ). The degree of complexity is partly a function of how long the moulin was active. All moulins studied have been found to drain downward into the ice rather than along the crevasses to the margin of the glacier. However, compared with moulins formed nearer the sides of the glacier, there is some tendency for those formed close to the kinematic center line to find straighter connections down into the deeper parts of the glacier. The moulins along the center line may stay open in the order of 10 years, while only $100 \mathrm{~m}$ from the center line they normally last for only 1 or 2 years. 

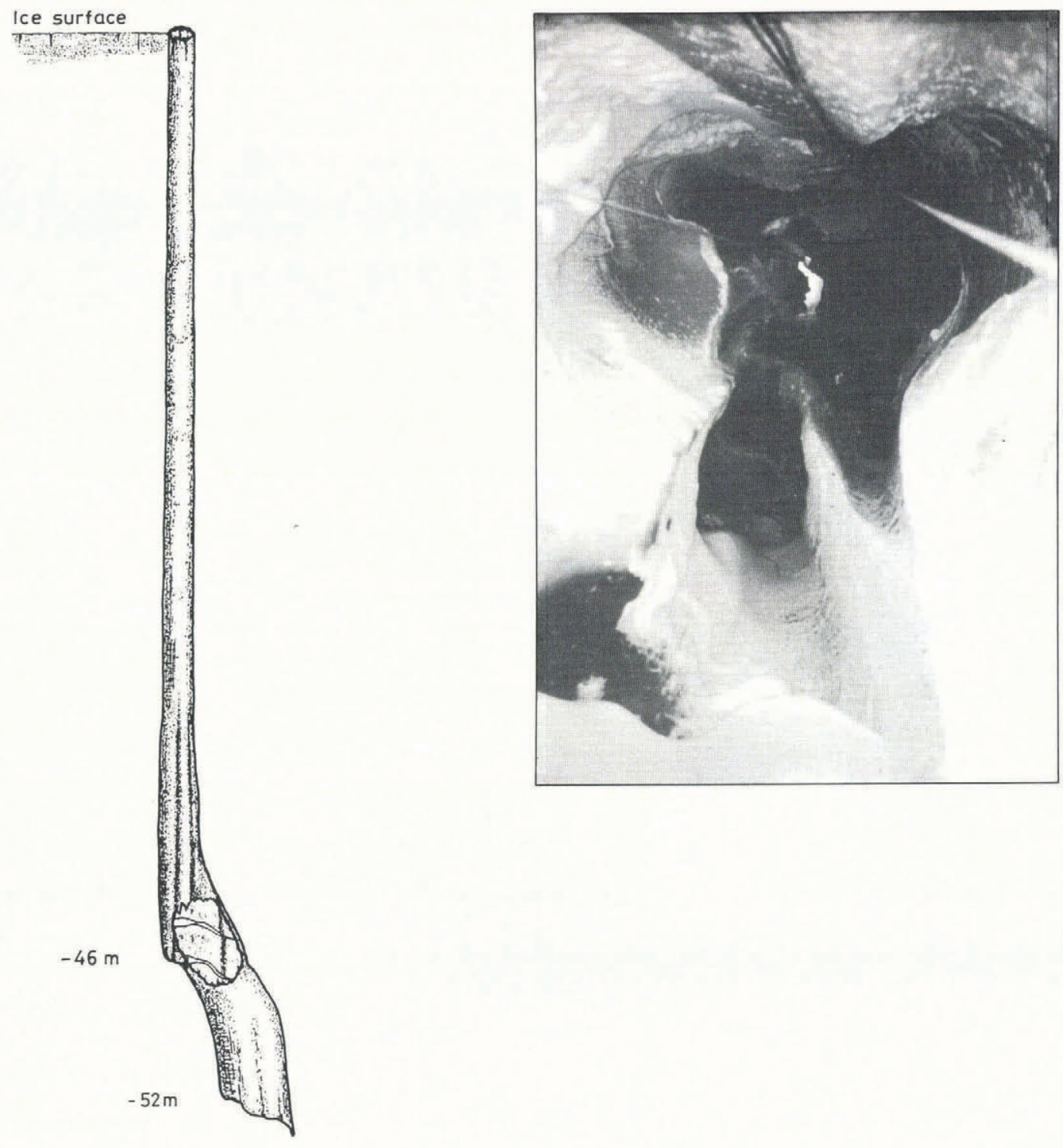

Fig. 6. Three-dimensional drawing and photograph showing the interior of moulin 78:1 in April 1979. The photograph is taken looking upwards from a depth of $43 \mathrm{~m}$ below the surface with a wide-angle lens. The white flecks are new snow from a blizzard between the two descents that were made.

Often, water-filled pockets appear at the glacier surface (Fig. 9). These are inferred to have been open parts of a conduit system that were air-filled during most of their path through the frozen layer, and that became filled with melt water as they melted out at the surface. It is likely that they maintained their downward connection with the hydraulic system in the glacier for some time after they were closed on the surface. Otherwise, they would have been water-filled and later frozen.

Widening of the moulins at depth has only rarely been observed in fossil moulins that have been mapped, perhaps because the lower parts of the moulins close by creep. An inactive moulin that stays open for some years will shrink significantly in the horizontal plane. This fact will make reconstruction of its original shape difficult and rather inaccurate. Moulin 68:1 in Figure 8 illustrates the problem rather well. From August 1982, when study of this exposure was initiated, until July 1984 this moulin was plugged with superimposed ice. In late July 1984 the last of that ice melted off and exposed ice that originated from freezing of water such as shown in Figure 4. The areal extent of this ice was less than half that of the superimposed ice. In this case, it is likely that the lower part was air-filled until the superimposed ice became so thin that melt water could penetrate through it and fill the cavity. The deeper structure is clearly part of the original moulin so there is no reason to believe that the observed decrease in the cross-sectional area corresponds to real change in its original shape.
About $5 \mathrm{~m}$ south of moulin 68:1 there is an other, 68:2 (Fig. 8), with a different shape. The ice structure filling this moulin is today somewhat bigger than that in $68: 1$; it is well rounded and shows no sign of deformation. Moulins $68: 1$ and $68: 2$ are connected to each other by a channel that was exposed from July 1980 until August 1982 (Fig. 8). This channel was straight and about $0.4 \mathrm{~m}$ wide. At the same time as this channel melted out, stones of different shapes and dead lemmings appeared in moulin 68:2. This moulin must therefore have lost its direct downward connection with the englacial water system, earlier than did moulin 68:1. It then functioned as a plunge pool for descending water which overflowed along the channel to moulin $68: 1$. Stones that were washed or thrown in collected in this pool.

\section{Water levels in moulins}

During high-water events, which normally occur daily during warm weather but with different magnitudes each day, it is possible to study the internal connections between moulins. While monitoring moulins formed in the same crevasse, the water levels of ten rise with different speeds corresponding to the capacity of and input to each individual englacial system. When the water level in one moulin reaches the original drainage channel connecting the moulins in the crevasse, the water flows along the channel and fills the other moulin until the pressure is equal in both. If the water level continues to rise, it will be equal in adjacent interconnected moulins, thus forming a local 
water table. However, there is so far no evidence for a large-scale water table over the entire glacier.

\section{DISCUSSION}

Shreve (1972) has shown that equipotential planes in the ice dip up-glacier at an angle approximately 11 times the surface slope. Water flow should be normal to these planes, if the ice is deforming, so that the pressure in the englacial channel is effected by the overburden pressure. In

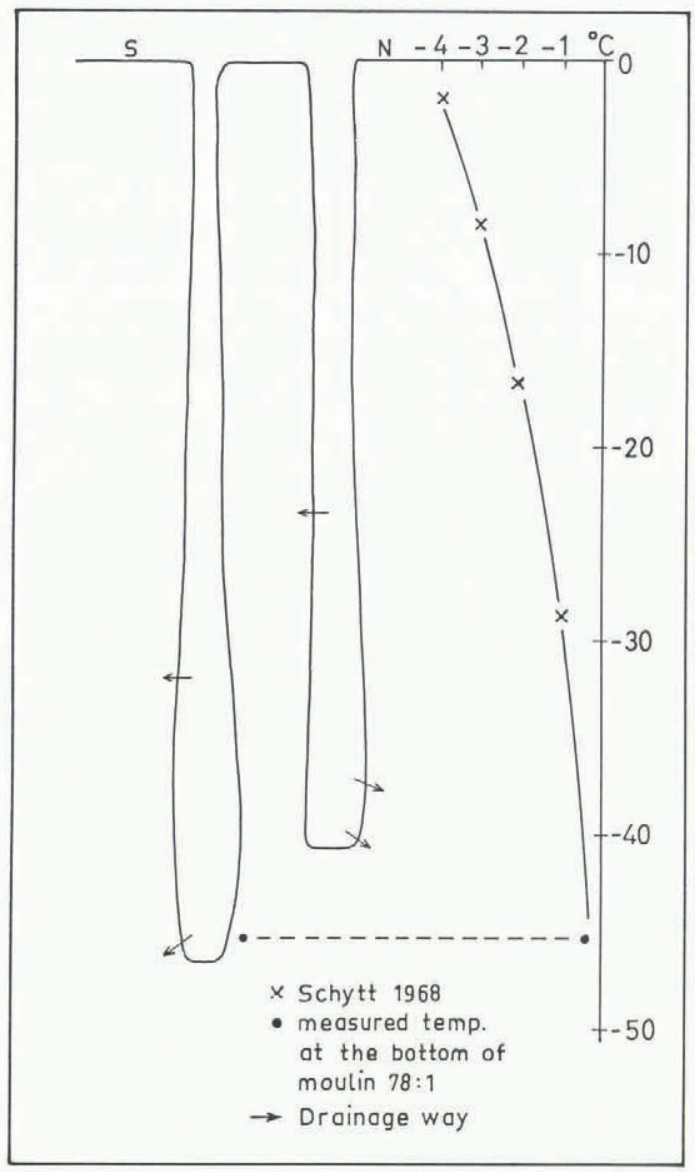

Fig. 7. Ice temperature and geometry of moulins $78: 1$ and 81:1. The temperature measurement at $45 \mathrm{~m}$ was made in April 1979. The temperature was $-0.35^{\circ} \mathrm{C}$ at $20 \mathrm{~cm}$ as well as at $100 \mathrm{~cm}$ into the ice of the wall. the area under investigation on Storglaciären, this means that the veins or channels would dip approximately $40^{\circ}$ down-glacier. The initial channels intersected by crevasses are probably finger-tip tributaries in this system, but they would rapidly be enlarged by melting, utilizing mechanical energy released by descending water.

So far there are no observations of this down-glacier dip of conduits from Storglaciären. Two possible explanations for this can be given. First, the fact that the general pressure in this uppermost part of the englacial water system is atmospheric or close to atmospheric. During the winter, when no melt water is produced at the surface, local water levels may be up to about $40 \mathrm{~m}$ below the glacier surface (Holmlund and Hooke, 1983, fig. 4, p. 22). During the melt season, the water level only occasionally reaches this level and there is only one observation in which water has reached the glacier surface and flooded over (Holmlund, unpublished). Thus, the hydrostatic pressure in the ice may not influence the geometry of the near-surface drainage system to any great extent, as the water pressure in the conduits may be close to, or at, atmospheric pressure most of the year.

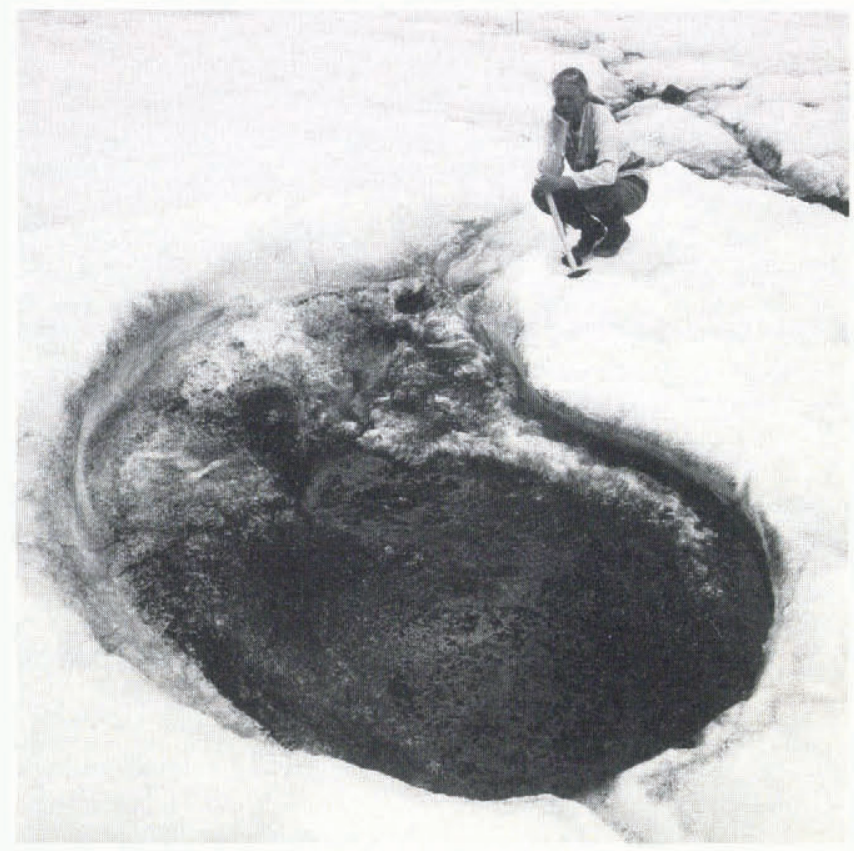

Fig. 9. Structure 68:4 at site 1 (Figs 2 and 3) in August 1984. This structure appeared as a water-filled pocket which later froze on the glacier surface. A vertical section is shown in Figure 8.

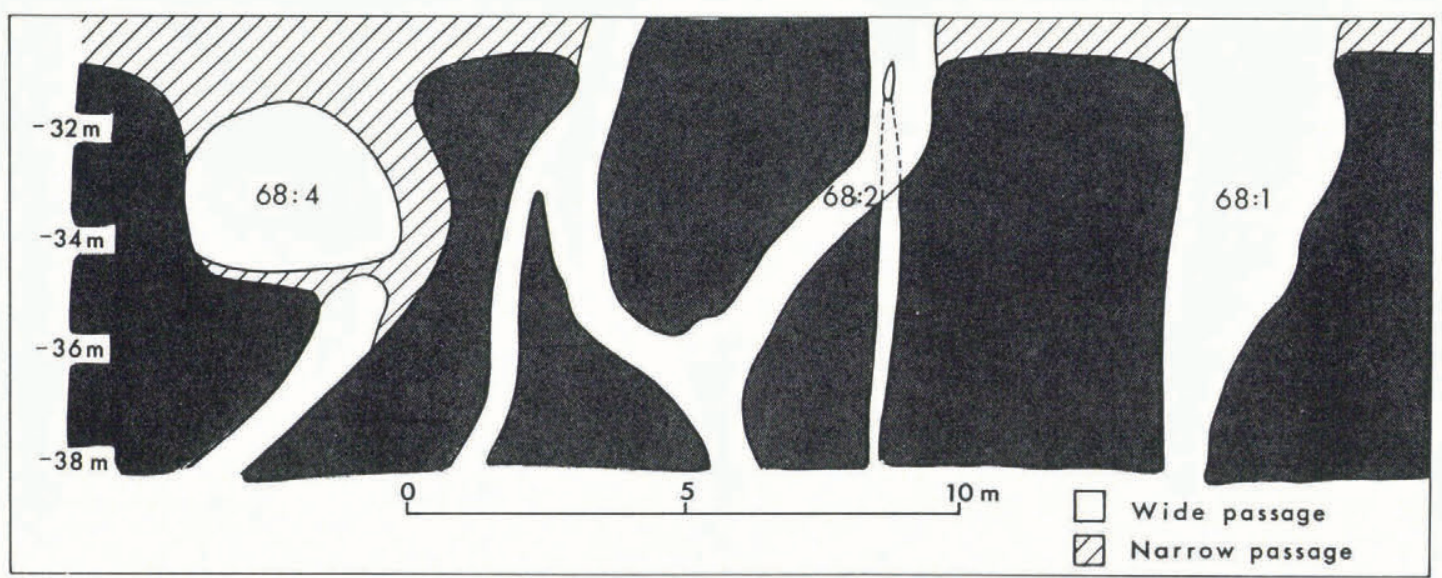

Fig. 8. Reconstruction of four interconnected moulins as inferred from successive detailed maps. Structures are projected on to a plane transverse to the glacier flow. The drawing is an interpretation from 18 maps with vertical spacing based on measured ablation. Wide passages are normally vertical shafts while narrow ones $(0.2-0.4 \mathrm{~m}$ perpendicular to the plane of the diagram) are meandering channels between shafts. 
Alternatively, the crevasses in this area may be deeper than previously thought. In the area investigated, the glacier flows over a bedrock riegel causing crevasses due to extending flow. The subglacial hydrological activity is high during the melt season, causing an uneven ice velocity. At several locations in this area, interconnecting conduits between moulins have been observed at depths between 20 and $30 \mathrm{~m}$. In Figures 5 and 8 , interconnecting channels can be seen at depths down to about $30 \mathrm{~m}$. It is reasonable to assume that they are situated at the depth of the original crevasse. The deepest crevasse was observed in the wall of moulin 78:1 (Fig. 8) as a string-like structure at a depth of $42 \mathrm{~m}$. Such connecting channels melt downward by heat dissipated in the melt water, causing a meandering pattern such as has been observed at the bottom of moulins (Holmlund and Hooke, 1983, fig. 4, p. 22). The fact that the direction of these channels parallels that of the crevasse, down to the point where the crevasse intersects an englacial drainage channel, is perhaps not a surprise, but a little more puzzling is the fact that even the englacial channels, irrespective of the slope angle, do not diverge from the direction of the crevasse, even at depths of $50-60 \mathrm{~m}$.

\section{CONCLUSIONS}

The internal geometry of moulins is influenced by the amount of water pouring into them, by the depth and width of the original crevasse, and by the temperature distribution in the glacier.

The moulins in the area investigated are normally $30-40 \mathrm{~m}$ deep and have a distinct bottom. Descents into moulins and mapping of structures exposed at the surface after many years of melting demonstrate that the drainage channels leading down from the bottoms of the moulins have inclinations of $0-45^{\circ}$. These channels trend in the direction of the original crevasse, but appear to be deeper than $35-45 \mathrm{~m}$ which is the observed depth of the crevasse. They are not, even at depths of $50-60 \mathrm{~m}$, normal to the equipotential planes described by Shreve (1972).

\section{ACKNOWLEDGEMENTS}

I am most grateful to Professor R. Hooke for his critical comments on the manuscript and on the English text. The field work was inspired and greatly aided by the late Professor V. Schytt. Thanks are due to the people at the Tarfala research station for their assistance during my field work; thanks are also due to S. Bergfelt and $E$. Granbom who drew the illustrations. Finally, I should like to thank C. Bronge for helping me with the computations of the three-dimensional figures.

\section{REFERENCES}

Dewart, G. 1966. Moulins on Kaskawulsh Glacier, Yukon Territory. Journal of Glaciology, 6(44), 320-31.

Holmlund, P. Unpublished. Glaciärbrunnars genes och morfologi. University of Stockholm. Department of Physical Geography.

Holmlund, P., and Hooke, R. LeB. 1983. High water-pressure events in moulins, Storglaciären, Sweden. Geografiska Annaler, 65A(1-2), 19-25.

Hooke, R. LeB., Gould, J.E., and Brzozowski, J. 1983. Near-surface temperatures near and below the equilibrium line on polar and subpolar glaciers. Zeitschrift für Gletscherkunde und Glacialgeologie, 19(1), 1-25.

Parker, G. 1975. Meandering of supraglacial melt streams. Water Resources Research, 11(4), 551-52.

Raymond, C.F., and Harrison, W.D. 1975. Some observations on the behavior of the liquid and gas phases in temperate glacier ice. Journal of Glaciology, 14(71), 213-33.

Reynaud, L. 1987. The november 1986 survey of the Grand Moulin on the Mer de Glace, Mont Blanc Massif, France. Journal of Glaciology, 33(113), 130-31.

Schytt, V. 1968. Notes on glaciological activities in Kebnekaise, Sweden during 1966 and 1967. Geografiska Annaler, 50A(2), 111-20.

Shreve, R.L. 1972. Movement of water in glaciers. Journal of Glaciology, 11(62), 205-14.

Stenborg, T. 1968. Glacier drainage connected with ice structures. Geografiska Annaler, 50A(1), 25-53.

Vallot, J. 1898. Exploration des moulins de la Mer de Glace. Annales de l'Observatoire du Mont Blanc, 3, 183-90. 